\title{
THE ROLE OF LOCAL GOVERNMENTS IN EMPOWERING FARMERS IN DOGIYAI REGENCY
}

\author{
By \\ Giofani Inge Aria $\mathbf{H}^{1}$, Supardal ${ }^{2}$ \\ ${ }^{1,2}$ Sekolah Tinggi Pembangunan Masyarakat Desa "APMD” \\ Email: 19iofaniingearia@yahoo.co.id, 2drsupardal@gmail.com
}

\begin{tabular}{l}
\hline \hline Article Info \\
\hline Article History: \\
Received Nov 13, 2021 \\
Revised Dec 22, 2021 \\
Accepted Jan 24, 2022
\end{tabular}

Keywords:

Government, Community

Empowerment, Farmer

\begin{abstract}
Natural potential in agriculture has a very important role in meeting the food needs of the community, but due to the lack of empowerment of human resources, not all farmers can take advantage of the existing natural potential. For this reason, the role of the Department of Agriculture and Plantation of Dogiyai Regency is needed in community empowerment in the agricultural sector so that human resources can be empowered to manage the existing natural potential. The research method used in this research is qualitative research with data collection techniques using three ways, namely observation, interviews and documentation.Data analysis techniques used include: data collection, data reduction, data presentation, and drawing conclusions.The results of the study show that the empowerment program in the form of: a) Training and Coaching, b) Providing Counseling and Mentoring, and c) Providing Facilities and Infrastructure, has been running quite well but for now it is still hampered due to the Covid-19 outbreak.The inhibiting and supporting factors in the empowerment process carried out by the Department of Agriculture and plantations on farmers are Supporting Factors, in the form of: a) The existence of farmer groups, and b) The existence of community participation. Inhibiting factors, in the form of: a) Lack of agricultural extension experts, b) Lack of the next generation of agriculture, and c) Lack of clear institutions
\end{abstract}

Thisisan open accessarticleundertheCC BY-SAlicense.

\section{CorrespondingAuthor:}

Giofani Inge Aria $\mathrm{H}$

Sekolah Tinggi Pembangunan Masyarakat Desa "APMD”

Email: giofaniingearia@yahoo.co.id

\section{INTRODUCTION}

Indonesia is a country rich in natural resources. Indonesia is an agrarian country with a strategic geographical location, thus supporting the existence of abundant natural resources both in terms of the agricultural, forestry, marine, fisheries, livestock, plantation and mining sectors. However, abundant natural resources are not supported by adequate human resources. This results in many Indonesian people who are not yet prosperous due to their lack of ability to manage and utilize existing natural resources. To improve the welfare of farmers in utilizing their natural potential, the government made Law Number 19 of 2013 concerning the Protection and Empowerment of Farmers, the purpose of the law was to realize the sovereignty and independence of farmers, provide facilities and infrastructure, protect farmers from price fluctuations, increase the capacity and per capita of farmers, and develop agricultural financing institutions that serve business interests. In addition to the law, there are also regional regulations that support the implementation of the protection and empowerment of farmers, namely the Governor of Papua Regulation Number 13 of 2015 concerning Technical Provisions, Terms and Procedures for Farmer Empowerment. The purpose of the governor's regulation is to promote and develop the mindset and work patterns of farmers, improve farming and grow and strengthen farmer institutions so that they are able to be independent and highly competitive. To realize all these goals, it is the duty of the government, especially local governments, to improve the welfare of the community which can be realized by empowering farmers with various programs to advance human resources in managing existing natural resources.

Empowerment of farmers is one of the efforts to improve the welfare of the community, through several activities including increasing community initiatives and self-help, developing farmers' businesses, developing farmers' finances, as well as activities that can increase farmers' ability to increase their yields and production. These 
efforts are expected to be able to improve the quality of human resources in order to achieve a higher quality of life. In addition, community empowerment is an effort to provide power or increase empowerment which can be interpreted as an effort to make the community independent so that they are able to actively participate in all aspects of development.

Dogiyai Regency is a district that is rich in natural resources. Especially in the agricultural, forestry, fisheries, livestock, plantation and mining sectors. Dogiyai Regency consists of 10 districts and 79 villages with an area of 4,237 km2Most of the people in Dogiyai Regency, especially the Kamuu District community, have professions as farmers of vegetables, corn, bananas, beans, sweet potatoes, cassava, taro, potatoes, coffee and some fruits. This is certainly a natural potential that can be utilized by the community to improve their economy so that they can prosper. For this reason, it is necessary to support the local government, namely the Department of Agriculture and Plantation of the Dogiyai Regency, to empower farmers, so that large and empty land can be used for farming not only to meet the needs of their own households but also to meet the needs of the people in the Regency. Dogiyai and other regencies around Dogiyai Regency, thus the existing farmers can support the creation of community welfare and can increase the economic income of the farming community itself.

\section{LITERATURE REVIEW}

\section{The Role of Local Government}

According to the Big Indonesian Dictionary, the role is a set of behaviors that are expected to be possessed by people who are domiciled in society. So it can be said that the role is a behavior that other people expect to have someone who has a certain position or position in a system. Usually someone gets a role because of social influences both from inside and outside that are stable. There is also the role of government according to Adam Smith (1776) in Kuncoro (2010:260) which consists of only three functions, namely:

a. Maintain domestic defense and security.

b. Organizing justice.

c. Provide goods that cannot be provided by the private sector.

From the above theory it can be said that the government is required to play a fair role for the whole community. If it is associated with this research, the Department of Agriculture and Plantation is expected to empower local farming communities so that they can have adequate sources of knowledge, so that local farmers can increase crop yields and can increase the productivity of foodstuffs that have good selling value, so that they can advance the economy of local farmers. fairly and equitably.

\section{Community Empowerment}

According to Anwas (2014: 58-60) in empowerment activities, especially those aimed at the community, empowerment officers/agents need to hold several principles in community empowerment, which become a reference in implementation so that activities can run correctly and appropriately, in accordance with the nature and concept of empowerment. Some of the principles of community empowerment in question include:

a. Empowerment is carried out in a democratic manner, full of sincerity, there is no element of coercion, because every community has different problems, needs, and potentials, so they have the same rights to be empowered

b. Every empowerment activity community should be based on the needs, problems, and potential of the target group. This can be clearly seen if the identification and socialization process in the early stages takes place with the full involvement of the target group.

c. The main target of empowerment is the community, so it must be positioned as a subject/actor in empowerment activities, and become the main basis in setting goals, approaches, and forms of empowerment activities.

d. Re-growing cultural values and local wisdom, such as the spirit of gotong royong, the young respecting the elders, and the older loving the younger ones, because this becomes social capital in development.

e. It is carried out in stages and continuously, because it is a process that takes time, is carried out logically and simply leading to more complex things.

f. Pay attention to the diversity of character, culture and habits of the community that have been rooted or have lasted for a long time from generation to generation.

g. Paying attention to all aspects of community life, especially social and economic aspects.

h. There is no element of discrimination, especially against women9. Always apply a participatory decisionmaking process, such as timing, materials, activity methods and others.

i. Mobilizing community participation in various forms, both physical (materials, labor, materials) and nonphysical (advice, time, support) 
International Journal of Social Science (IJSS)

Vol.1 Issue.5 February 2022, pp: 767-774

ISSN: 2798-3463 (Printed) | 2798-4079 (Online)

DOI: https://doi.org/10.53625/ijss.v1i5.1321

j. Empowerment officers/agents act as facilitators who must have abilities/competencies according to potential, needs, problems facing society. Willing to cooperate with all related parties/institutions and community institutions/NGOs.

From the theory above, it shows that there are 10 principles in community empowerment that need to be considered when empowering the community. This is necessary so that the empowerment process carried out can run well in accordance with what is needed by the community and the benefits of empowerment itself can be felt. After everything is considered correct, then the next process is the empowerment stage which can be done so that the empowerment process can take place in good and correct stages. According to Soekanto (1987) in Sugiyanto (2021: 130-131) there are 7 stages of community empowerment, namely;

a. Preparation, at this stage there are 2 things that need to be done: 1 ) preparation of officers, namely community empowerment which can be carried out by community wokers, and 2) field preparation which is basically carried out in a non-directive manner

b. Assessment (assessment), this stage is an assessment that can be done individually through groups in the community.

c. Planning alternative programs or activities, at this stage the officers (facilitators) as agents of change in a participatory manner try to involve residents to think about how to overcome them.

d. Formalization of the action plan, at this stage, the facilitator helps each group to formulate and determine the program and activities that will be carried out to overcome the existing problems.

e. The implementation of the program or the implementation of activities, the community as cadres, in the implementation of community empowerment is expected to maintain the continuity of the programs that have been developed.

f. Evaluation, evaluation of ongoing community empowerment should be carried out by involving residents of program recipients, so that in the short term they can form a monitoring community system internally and in the long term they can build more independent community communication by utilizing existing resources, especially human resources. social, and political and economic resources

g. Termination, this stage is the stage of formally terminating the relationship with the target community, at this stage it is also expected that the project must stop immediately.

\section{Farmers}

According to Law Number 19 of 2013 concerning the Protection and Empowerment of Peasants, farmers are Indonesian citizens who are individuals and/or and their families who carry out Farming Business in the fields of food crops, horticulture, plantations, and/or livestock. Meanwhile, according to Law Number 19 of 2013 concerning the Protection and Empowerment of Farmer Community, a farmer group is a collection of Farmers/breeders/planters formed on the basis of common interests, common conditions of social environment, economy, resources, common commodity, and familiarity to improve and develop member effort.

According to Yuwono (2018:4) farmers have unique characteristics for each region, which affect the pattern of farming they cultivate. The more complex the characteristics of farmers, the more diverse the agricultural businesses that are carried out and run. The following are the common traits possessed by a farmer.
a) Farmers as individuals
b) Farmers live below their means
c) Farmers are the conclusion group
d) Farmers are different from each other
e) Most farmers are bound by habits
f) Farmers are trying to get something
g) Farmers are suspicious and reluctant to new things
h) Farmers appreciate good service and agreement from family and neighbors
i) Farmers do not like being pressured and given instructions on what to do

\section{RESEARCH METHOD}

The type of research used in this research is descriptive qualitative research. This study aims to describe existing phenomena, both natural and human engineered, which will then be described in words based on what has been observed and explored further. The object of research in this study is the role of local governments in empowering local farming communities in the Department of Agriculture and Plantation of Dogiyai Regency. Data collection techniques in this study used three ways, namely observation, interviews and documentation. The data analysis techniques used include: data collection, data reduction, data presentation, and conclusion drawing. 


\section{RESULT AND DISCUSSION}

Dogiyai Regency is one of the regencies in Papua Province which is located in the central mountains. 136.37' East Longitude and $3^{\circ} .57^{\prime}$ South Latitude $-4.15^{\prime}$ South Latitude. Dogiyai Regency is one of the districts in Papua Province which is located in the Central Mountains of Papua with an area of approximately $\pm 7,052.92$ square kilometers, with regional boundaries as follows:

North side: $\quad$ Siriwo District, Nabire

Regency East side: Paniai District, Paniai

Regency: $\quad$ West Mimika District, West Mimika

Regency: $\quad$ Uwapa District, Kab. Nabire, Kaimana Regency

The population of dogiyai district in 2019 based on the results of the population registration at the end of 2019 reached a population of $\pm 107,741$ people with a density of more than 500 people per $\mathrm{km}$ square. This condition is considered very dense when compared to the two regencies, namely, Paniai Regency and Deiyai Regency.

This analysis was conducted to find out and describe the role of local governments in empowering local farming communities in Kamuu District, Dogiyai Regency, so to get clear data and information, of course, several informants are needed as supporters. part in the process of empowerment and being empowered. In this study the data were taken based on several criteria including age, gender, education, and occupation/position. From this information, research data is taken for analysis.

The Role of the Department of Agriculture and Plantations in Empowering Local Farming Communities In Kamuu District, Dogiyai Regency

Agriculture certainly has an important role in the development process where development is indispensable in an effort to reduce poverty, so as to improve the welfare of the community, especially the farming community. For this reason, the role of the Department of Agriculture and Plantation in empowering the community in the agricultural sector is needed so that the human resources they have can be of higher quality. Empowerment carried out by the Department of Agriculture and Plantation of the Dogiyai Regency, is often focused on the heads of farmer groups that have been formed, which then the group leaders will be tasked with teaching or distributing what they have learned to their group members. The following is the data on farmer groups in Dogiyai Regency:

Table 1. List of Farmer Groups in Kamuu District

\begin{tabular}{|l|l|l|l|l|}
\hline NO & \multicolumn{1}{|c|}{ POKTAN } & \multicolumn{1}{|c|}{ /DISTRICT } & \multicolumn{1}{|c|}{ HEAD OF FARMING GROUP } & $\begin{array}{c}\text { NUMBER } \\
\text { OF }\end{array}$ \\
\hline 1 & MAKAM0 & Putapa/ Kamuu & Marsela Dogomo & 30 \\
\hline 2 & POUYA & Putapa/ Kamuu & Aleks Yobee & 20 \\
\hline 3 & BUKAPAKOTU & Bukapa/ Kamuu & Yosias Iyai & 25 \\
\hline 4 & MAUWABA & Mauwa/You & Ance Iyai & 20 \\
\hline 5 & WAUMANI & Mauwa/You & Yustina Bobi & 25 \\
\hline 6. & AWATA & Ikebo/You & Nonce Boma & 27 \\
\hline 7 & ONEPA & Putapa/You & Yopin Dogomo & 15 \\
\hline 8 & MAUWAPE & Mauwa/You & Albertina Tebai & 10 \\
\hline 9 & NUWAIDA & Ekemanida/You & Germanus Goo & 20 \\
\hline 10 & IDAKOTU & Idakotu/You & Akulina Yobee & 19 \\
\hline 12 & PUGAWO & Dikiyouwo/You & Nonce Tebai & \\
\hline
\end{tabular}


International Journal of Social Science (IJSS)

Vol.1 Issue.5 February 2022, pp: 767-774

ISSN: 2798-3463 (Printed) | 2798-4079 (Online)

DOI: https://doi.org/10.53625/ijjss.v1i5.1321

\begin{tabular}{|l|l|l|l|l|}
\hline 13 & MAGO & Kimupugi/You Dorkas & Agapa & 15 \\
\hline 14 & TOKAPO-2 & Mauwa/Anda & Amos Goo & 35 \\
\hline
\end{tabular}

Source: SK POKTAN Department of Agriculture and Plantation of Dogiyai Regency

With the formation of farmer groups based on The table above makes it easier for the Dogiyai Regency Agriculture and Plantation Service to empower farmers. In line with that, what the Agriculture and Plantation Service does is to empower local farmers in Kamuu District, Dogiyai Regency, namely: 1. the role of local governments in the form of training

And coaching Agricultural training and coaching is carried out in order to improve the ability of farmers in terms of knowledge, skills, up to agricultural management. To make this happen, the Dogiyai Regency government, especially the Agriculture and Plantation Service, has training and coaching program for farmers. This can be evidenced by the results of interviews with the Head of Plants that the researchers got as follows:

"Yes, there must be, we often do training for farmers, some of which we even sent to Bogor to attend training there, and now there are those who have succeeded in farms like mama Dorkas, Nonce, etc. We give all of that training and we leave to take part in the training" (Interview with Plant Headquarters, September 2021)

"Yes, from the government there is providing training and seed assistance" (results of interviews with farmers, September 2021) The several training programs carried out by the Department of Agriculture and Plantation of Dogiyai Regency are:

a. Training on procedures for using organic fertilizers

Training on procedures for making organic fertilizers

Training and socialization for farmers and agribusiness actors

This information can show that the Department of Agriculture and Plantation has performed its role in providing training and coaching to farmers in the Kamuu District so that now there are farmers who have succeeded in managing their gardens well. It's just that the community empowerment program for local farmers in the form of training and coaching has not been running optimally at this time due to the Covid-19 outbreak which resulted in most of the funds in the Dogiyai Regency government being diverted for Covid-19.

2. The role of local governments in the form of counseling and mentoring

Counseling and assistance to local farmers is of course very necessary in order to be able to assist, direct, and support local farmers through problem formulation, planning, implementing, and evaluating in farming business development. In practice, agricultural extension workers also act as facilitators so that farmers can make their own decisions. The task of extension workers and assistants is to help farmers to identify potential areas, identify and analyze markets, identify business potentials, identify and solve problems, and make decisions at the farmer group level. So it can be said that agricultural extension workers and assistants actually have an important role in advancing agriculture in Kamuu District, Dogiyai Regency, because they have an important role as a connector for local government programs to farmers and assisting farmers in the process of improving the quality of farmers in order to increase farmer productivity. . However, agricultural extension workers themselves are still very minimal in Dogiyai Regency itself, the shortage of agricultural extension workers has resulted in the lack of a good empowerment process, resulting in inadequate quality of farmers in Dogiyai Regency, lack of agricultural extension workers or employees, it has been proposed to hold the formation of agricultural extension workers. but not yet approved. This can be proven from the results of interviews with the head of plants that the researchers got as follows:

"...we are limited in extension workers compared to the old District era; there was extension in every village. It was only after becoming a district that there were no extension workers. So that's our obstacle to assisting farmers, not like before, every UPT has an instructor, so farmers want to work, if there is an instructor there. So now it's just us who are in limited service, sometimes we visit once and immediately finish, we have written many times to the district to organize formation of extension workers, we ask for formation for every village there is an extension worker at least for every sector there is at least every village there are and each sector is there. So each village has at least 4 extension workers with livestock, fisheries, plantations, agriculture, just like in the district era, but there hasn't been any until now" (interview with Head of Plants Division and Head of BPP, september 2021)

The support for farmer institutional development in Kamuu district is as follows:

a. Recruitment of assistant staff throughout 2020-2023 as many as 8 people

b. Make farmer's studio during 2020-2023 as many as 4 units

c. Provide extension facilities as much as 4 packages

d. Carry out institutional development or farmer groups as much as 2 activities per year starting from 2020-2023. 
The information above shows that the role of the government in the form of counseling and coaching already exists, but it has not been able to run optimally so that the task of the extension worker has not been able to be carried out properly. Due to the lack or limited number of agricultural extension workers, support from the local government is needed in order to meet the needs of the Department of Agriculture and Plantation so that farmers in Kamuu District can continue to develop and innovate properly.

3. The role of local government in providing farmers' facilities and infrastructure

The local government of Kamuu District in Dogiyai district has taken action to prohibit the entry of food from other districts, namely Nabire District, Deiyai District, and Paniai District. This is certainly a good start for farmers in Dogiyai district to be able to develop and innovate to meet the needs of the people in Dogiyai district. But of course the farmers need the facilities and infrastructure from the government that can increase the productivity of farmers, because food is a basic need for the community which must be met at all times, because if food availability is less than on the needs of the community will have an impact on economic instability, various social and political upheavals, which in turn will disrupt food security. To support the action of your district head which prohibits the entry of food from outside the Dogiyai district, the provision of facilities and infrastructure for farmers is certainly needed to increase productivity and production.

The forms of support for facilities and infrastructure are prepared to support farmers in Dogiyai Regency, namely providing production facilities according to the needs of the community in each village as follows:

a. Production Road and Farming Business Road.

b. Organic Fertilizer and Vegetable Pesticide

c. Small Farm Equipment (APK)

d. Product Processing Unit Development (Procurement of Machine Tools, Construction of Raw Material Warehouse, Product Processing Building, Green House Bean and other facilities).

Almost every year these facilities have been organized by the local government through the Department of Agriculture and Plantation. The provision of infrastructure in the form of seeds, fertilizers and tools and materials for farming is something the government has already done, but it turns out that behind all this, farmers still feel that it is still lacking, because not all farmers understand the steps to plant seeds. Packaging is good and correct, most of them are just thrown on the ground, and some are even resold. This can be proven by the results of interviews with farmers as follows:

"So the problem of seeds is what we are still struggling with, so according to the mothers, they hope that the government should build nurseries in strategic areas or areas, so the government has maps of these areas. The horticultural development center there must be prepared for a green house for nurseries so farmers don't need to give us sachet seeds anymore, but they are seeds. So it is hoped that the role of the government is to create strategic locations. the government builds seed breeding centers so that farmers don't have a problem and they just plant it because so far what has been distributed in the sachets has been resold because they want to do it. Is the job difficult? They don't really understand that. Scattered, even though the process has to be ripened first and there are many other stages, then full supporting infrastructure, of course, yes, polybags must be prepared" (results of interviews with farmers, September 2021)

This shows that farmers have difficulty developing the packaged seeds given, due to limited knowledge, therefore what farmers hope for is a center that develops seeds in each strategic location, so that what is given to them is no longer in the form of packaged seeds, but in the form of seeds that are ready to be planted .

The information above shows that the role of the government in providing facilities and infrastructure already exists, it's just that the provision of facilities and infrastructure provided by the government is deemed not effective by farmers because not all farmers have the ability to manage and utilize the infrastructure provided properly, not all farmers can manage packaged seeds provided by the government because they do not understand the exact steps on how to manage these seeds so that some just scatter the seeds on the ground and some sell back the assistance provided by the government. Therefore, the farmers expect the government to build green hauses at several strategic points to develop the existing packaged seeds and then the people just receive the seeds that are ready to be planted.

District

Supporting and inhibiting factors for empowering local farming communities in Kamuu District, Dogiyai

\section{Supporting}

Factors supporting factors are factors that are very influential in every action taken by the local government in the process of empowering local farming communities in Kamuu district, Dogiyai district. The following are supporting factors:

a) The participation of farmers 
International Journal of Social Science (IJSS)

Vol.1 Issue.5 February 2022, pp: 767-774

ISSN: 2798-3463 (Printed) | 2798-4079 (Online)

DOI: https://doi.org/10.53625/ijss.v1i5.1321

. The existing empowerment program certainly requires the participation of farmers to take part in it, for the sake of an empowerment program that is useful and beneficial for the development of farmers in Kamuu District, Dogiyai Regency. This can be supported by the statement from the interview as follows:

"Yes, of course, in the implementation of the empowerment program that we create, we need the participation of farmers as our target, because we created this program for them, and so far farmers are still participating whenever we are invited to participate training, socialization and other activities." (Results of interview with plant head office, September 2021)

The above information shows that the participation of farmers in supporting empowerment programs carried out by the government already exists and supports the empowerment program, without participation farmers will certainly hinder the planned program. For this reason, participation is one of the supporting factors for farmer empowerment in Kamuu District, Dogiyai Regency.

b) The formation of farmer groups

In the process of implementing community empowerment, of course, farmer groups are needed that can support and motivate each other to develop, besides that it can also make it easier for the government to empower existing farmers through existing farmer groups. This is supported by the formation of farmer groups that have groups and group members. Where there are 14 farmer groups in Kamuu District.

2. Inhibiting

Factors inhibiting factors are factors that hinder the process of empowering local farming communities in Kamuu District, Dogiyai Regency. The following are inhibiting factors:

a) Lack of expert agricultural extension workers Agricultural

Extension workers are certainly needed because they have an important role as a connector for local government programs to farmers and assist farmers in the process of improving the quality of farmers in order to increase farmer productivity. So that farmers can identify potential areas, identify and analyze markets, identify business potential, identify and solve problems, and make decisions at the farmer group level. However, the number of agricultural extension workers in Dogiyai Regency is limited. This can be proven by the results of the interview as follows:

"The Department of Agriculture has prepared a pilot site so that there is a Gapoktan, a Poktan, a farmer group, or an individual farmer group. So they have a need for cultivation problems, convey them to BPP here, now the bridge. Who is the Agricultural Instructor, he is the one who backs up the farmers, prepares the work plans for the farmer groups and farmers, then the potentials there are brought and processed here and submitted to the service so that they happen making the program after the program was dropped according to the proposal returned to the UPTD then processed and submitted to the farmers the route is like that, only so far we have never managed this is the problem" (results of interview with Head of Plants and Head of UPTD, September 2021)

In addition, due to lack of clear institutions this resulted in farmers who did not really understand the process of planting packaged seeds, in the end there were those who just scattered them on the land and some sold them back. This can be proven by the results of interviews as follows:

"So the problem of seeds is what we are still struggling with, so according to the women, they hope that the government should build nurseries in strategic areas or areas, so the government has maps of horticultural development centers. there, a green house must be prepared for nurseries so that farmers no longer need to give packaged seeds, but they are seeds. So it is hoped that the government's role is to create strategic locations, the government is to build seed breeding centers so that farmers don't have problems and they just plant because so far, most of the packaged seeds have been sold because they don't want to do what the job is, they don't bother. I understand too much for that, usually Mama, if you buy packaged seeds, they are immediately scattered, even though the process has to be ripened first and so on, there are many stages. (Results of interviews with farmers, September 2021)

The information above shows that clear institutions are really needed in local farmers in order to support the level of productivity in order to meet the needs of the community in Dogiyai Regency. Due to the lack of institutional clarity, the government's task cannot be carried out effectively because it only goes to the field to check on the condition of the farmers a few times. In addition, it resulted in the failure of existing farmer groups, due to lack of motivation and direction, resulting in jealousy and suspicion of one another which resulted in the farming community preferring to work independently.

\section{CONCLUSION}

Empowerment of local farming communities is of course very much needed in order to increase farmer productivity and production of agricultural products. The role of the Department of Agriculture in empowering local 
farming communities in Kamuu District, Dogiyai Regency, is a) Providing Training and Guidance, b) Providing Counseling and Assistance, and c) Providing Facilities and Infrastructure. The supporting and inhibiting factors of the empowerment process carried out by the Agricultural and Plantation Agency for local farming communities in Kamuu District, Dogiyai Regency. Supporting factors, in the form of: a) The participation of farmers, and b) The formation of farmer groups. Inhibiting factors, in the form of: a) Lack of expert agricultural extension workers, b) Lack of the next generation of agriculture, and c) Lack of clear institutions

\section{REFERENCES}

[1] Adiwilaga, Anwas. 1992. Ilmu Usaha Tani: Cetakan II. Bandung: Alumni

[2] Anwas, Oos M. 2014. Pemberdayaan Masyarakat di era global. Bandung:Alfabeta

[3] Hamid, Hendrawati. 2018. Manajemen Pemberdayaan Masyarakat. Makassar : De La Macca (Anggota IKAPI Sulsel).

[4] Kuncoro, Mudrajad. 2010. Masalah, Kebijakan, dan Politik Ekonomika Pembangunan. Jakarta: Erlangga

[5] Mosher, A.T. 1997. Mengerakan dan Membangun Pertanian. Jakarta: Yasa Guna.

[6] Mardikanto, Totok dan Poerwoko Soebiato. 2013. Pemberdayaan Masyarakat dalam Perspektif Kebijakan Publik. Bandung : Alfabeta.

[7] Peraturan Gubernur Papua Nomor 13 Tahun 2015 tentang ketentuan teknis, syarat dan tata cara Pemberdayaan Petani

[8] Sastraatmadja, Etang. 2010. Suara Petani. Bandung: Masyarakat Geografi Indonesia.

[9] Sugiyanto. 2021. Manajemen Fasilitasi Dan Pemberdayaan Masyarakat. The Journal Publishing : CV The Journal Publishing, volume 2, issue 11, hal 1-442.

[10] Sugiyono. 2010. Metode Penelitian Kuantitatif, Kualitatif, dan R\&D. Bandung : ALFABETA.

[11] Sugiyono. 2013. Metode Penelitian Kuantitatif, Kualitatif, dan R\&D. Bandung : ALFABETA.

[12] Sugiyono. 2015. Metode Penelitian Kuantitatif, Kualitatif dan R\&D. Bandung : ALFABETA.

[13] Sugiyono. 2016. Metode Penelitian Kuantitatif, Kualitatif, dan R\&D. Bandung : ALFABETA.

[14] Suharto, Edi. (2010). Membangun Masyarakat Memberdayakan Rakyat. Bandung: Alfabeta

[15] Sumodiningrat, Gunawan. 2009. Pemberdayaan Masyarakat. Jakarta. PT Gramedia Pustaka Utama

[16] Totok Mardikanto dan Poerwoko Soebiato. 2012. "Pemberdayaan Masyarakat Dalam Prespektif Kebijakan Publik". Bandung : Alfabeta.

[17] Ndraha, Taliziduhu. 2001. Kybernologi. Jakarta : PT. Rineka Cipta.

[18] Rasyid. 2000. Makna Pemerintahan. Jakarta : PT. Mutiara Sumber Widya.

[19] Republik Indonesia. 2013. Undang-Undang RI Nomor 19 Tahun 2013 tentang Perlindungan Dan Pemberdayaan Petani, Jakarta: Presiden Republik Indonesia

[20] Republik Indonesia. 1945. Undang-Undang Dasar Negara Republik Indonesia Tahun 1945. Jakarta: Presiden Republik Indonesia

[21] Republik Indonesia. 2014. Undang-Undang Nomor 23 Tahun 2014 Tentang Pemerintahan Daerah. Jakarta: Presiden Republik Indonesia.

[22] Republik Indonesia. 2019. Peraturan Pemerintah Nomor 17 Tahun 2019 tentang Kecamatan. Jakarta: Presiden Republik Indonesia

[23] Yuwono, Triwibowo, dkk. 2018. Pengantar Ilmu Pertanian. Yogyakarta: UGM Press 